\title{
BiR ÖZ DENETIM PRATiĞi OLARAK ETKINLIK ÖLÇÜMÜ VE ÜNIVERSITELER
}

\author{
Yrd. Doç. Dr. Recep Varçın \\ Ankara Universitesi \\ Siyasal Bilgiler Fakültesi
}

\author{
Gül Ergün \\ Hacettepe Universitesi \\ Iktisadi ve Idari Bilimler Fakültesi
}

\section{Ōzet}

Bu çalışma Ankara Üniversitesi Siyasal Bilgiler Fakültesi tarafından yürütülmüş olan Istihdam ve Danışmanlık Hizmetleri eğitim programının etkinliğini ölçmeyi hedeflemektedir. Etkinlik araşturmasına ilişkin veriler, programa kathlan kursiyerlerle görüşme formu aracallğ ile toplanmıştır. Hedef-kitle merkezli yaklaşım ile sürȩ̧ araştırması yaklaşımlannun sentezi yapılarak tespit edilmeye çalışlan program etkinliği dört ana tema üzerinde irdelenmiştir. Bunlar, eğitim programının yürütüldüğü mekan, araç ve gereçlerin yeterliliği; kursiyerlerin eğitim programından kazanımlan; eğitim programunın kursiyerler üzerindeki etkisi ve programda ders veren öğretim üyeleri ile programdaki derslerin değerlendirilmesidir.

Anahtar Sözcükler: Hizmet içi eğitim, etki araşturması, istihdam hizmeti, eğitim hizmeti, sertifika eğitimi.

\section{An Impact Analysis as a Means of Self-Control and Universities}

\section{Abstract}

The Purpose of this paper is to examine the effectiveness of the Employment and Counseling Services training program being implemented by the Faculty of Political Sciences, Ankara University. We collected data via the face-to-face semi-structured interview technique with the program participants. We combined the methodological and analytical techniques of process evaluation and target-group approaches in examining the outcomes of the program impact which focus on the following themes: physical and training facilities; the contribution of the training program to program participants; the impact of the training program on program participants; and the assessment of the program instructors and training curriculum.

Key Words: In-service training, impact analysis, employment service, counseling service, certificate training. 


\section{Bir Öz Denetim Pratiği Olarak Etkinlik Ölçümü ve Üniversiteler*}

\section{GiRiş}

Pek çok şey gibi, üniversiteler de dünya çapında önemli bir dönüşüm sürecinden geçmektedir. Bilgi toplumuna ve yeniliğe (innovation) dayah rekabete yapilan vurgular, üniversitelerin toplumsal işlevini yeniden tanımlamak yönünde önemli bir basınç uygulamaktadır Bu çerçevede, kara Avrupa'sına uzun yıllar damgasın vuran Alman menşeili Humbalt modeli üniversite yapısı erozyona uğrarken, onun yerini "anglo-Amerikan" diye nitelendirilen modelin almaya başladığı söylenebilir (Gülbenkian Komisyonu, 1996). Anglo-Amerikan modelde, bilimsel bilgiyi üretme ve onu eğitim ve yayın yoluyla yayma faaliyetlerinin girişimci bir işletme örgütlenmesiyle yapılması savunulmaktadır (ÖZZLM, 1998; ÖZUĞURLU, 1998). Kısaca, "girişimci üniversite" modeli olarak bilinen bu yapı, Türkiye'de YÖK yasasındaki değişiklik önerilerinin de ana temasın oluşturmaktadır (Bkz. YÖK kanun tasarısı). Bu konudaki tartışmalar üniversite çevrelerinde devam etmekle birlikte metropol kentlerdeki kimi üniversiteler lisans ve lisansüstü müfredatlarınun dışına çıkarak çok çeşitli faaliyetler içerisinde bulunmaya başlamışlardır.

Kamu üniversitelerinin içine düşmüş olduğu mali sıkıntılar ve öğretim elamanlarının görece olarak gelir düzeyindeki erozyon kamu üniversitelerinin geleneksel olarak biçilen rolün dışına çıkmalarında hızlandırıcı bir rol oynamıştır. Kamu üniversiteleri, araştırma ve uygulama projeleri, danı̧̧manlık hizmetleri, sertifika programları gibi hizmetleri gerek kamu kuruluşlarına gerek özel kesime gerekse de toplumun bireylerine sunarak üniversitelere mali kaynak girişini sağlamaya çalışmaktadırlar. Söz konusu faaliyetler üniversite bünyesinde döner sermaye işletmesi üzerinden doğrudan örgütlenebildiği gibi, üniversite vakuflar ya da üniversite dernekleri gibi kuruluşlar ya da

1 Bu çalışma, çok geniş ve detaylı bir araştırmanın kısmi sonuçlarına dayanmaktadır. Bu çalışmada emeği geçen öğretim üyelerine, verileri kullanmamıza müsaade eden kişi ve kuruluşlara ve bu metni daha önce okuyarak bizlere eleştiri ve önerilerini ileten meslektaşlarımıza, programa katılan ve sorulara içtenlikle cevap veren kursiyerlere içten teşekkür ediyoruz. 
danışmanlık firmalan -özel firmalar- ile işbirliği içerisinde bulunularak dolaylı yoldan da örgütlenebilmektedir. Söz konusu faaliyetler kimi üniversitelerde daha da merkezi bir tarzda örgütlenmeye çalışılmaktadır: Örneğin ODTÜ'de SEM, Ankara Üniversitesi'nde ANKÜSEM oluşumu gibi. Üniversitelerin bu tür faaliyetler içerisinde bulunmalan söz konusu üniversitelere mali kaynak sağlarken ve üniversitelerin bazı temel giderleri (kütüphanelere yeni yayın alınması ve üniversitelerdeki tadilat işleri gibi) bu tür kaynaklardan karşılanurken, bu durum üniversitelerin ticarileşmesi olarak nitelendirilerek bu konuda önemli bir tepki de doğmaktadır.

Bu çalışma, üniversite sisteminin yeniden yapılanması hakkındaki tartışmalara girmeksizin, hal hazırda üniversitelerde yürütülen faaliyetler arasında önemli bir yer tutan ve bazı üniversitelerde oldukça yaygın olarak kullanılan sertifika programlarının etkinliğinin ölçülmesi ile kendisini sınurlandırmıştır. Zira son yıllarda bazı üniversiteler çok çeşitli alanlarda sertifika programlan ve kısa dönemli kurslar düzenlemektedirler ve bu konuda üniversiteler ya da ayn üniversitenin farklı fakülteleri arasında önemli bir rekabet de yaşanmaktadır. Bu filli gelişmeler karşısında, sisteme ilişkin tartşmalann yanısıra, yürütülen etkinliklerin değerlendirilmesi de önem arz etmektedir.

Ankara Üniversitesi Siyasal Bilgiler Fakültesi de geleneksel lisans ve lisansüstü müfredatına ilave olarak çeşitli alanlarda sertifika programlan ve kurslar düzenleyerek bu yeni oluşumda var olduğunu göstermektedir. Mühendisler Için Işletme Yönetimi Programı (MTYEP), Istihdam ve Danışmanlık Hizmetleri, ÇED ve Bilgisayar Eğitimi Siyasal Bilgiler Fakültesinin yürütmekte olduğu sertifika programlarının en yaygın olarak bilinenidir. Ancak üniversitelerin yürütmekte olduğu bu türden sertifika programlarınn gerçekten niyet edilen sonuçlara yol açıp açmadığı, bu tür programların etkinliğine ilişkin bilimsel araştırma gerçekleştirilmemiştir. Bu çalışmanun amaa bu konudaki boşluğu doldurarak, Siyasal Bilgiler Fakültesi tarafından yürütülmüş bulunan Istihdam ve Danısmanlık Hizmetleri Eğitim Programının etkinliğini bilimsel ölçütler çerçevesinde incelemek ve bu konuda araştırma yazınına katkı sağlamayı amaçlamaktadır. Çalışmanın takip eden bölümünde program etkinliğinin ölçülmesine yönelik kuramsal ve yöntemsel yaklaşımlar tartş̧ılacaktır. Bu bölüm, çalışmanun nasıl bir çerçeveye oturtulduğuna ilişkin temel bilgileri içerecektir. Daha sonraki bölümde program hakkında temel bilgilerle birlikte araşturmada kullanılan yöntem sunulacaktur. Daha sonra araşturmada elde edilen temel bulgular sunularak tartışlacaktır. Bu çalışma sonuç ve öneriler kısmı ile birlikte son bulacaktır. 


\section{PROGRAM DEĞERLENDíRILMESiNe KURAMSAL VE YōNTEMSEL YAKLAŞIMLAR}

Işgücü piyasasına yönelik olarak yürütülen eğitim programlarının etkinliğinin ölçülmesinde kullanulan yöntemsel yaklaşımlar son yıllarda önemli bir tartışma konusu olmuştur (SCHMID vd, 1996). Zira çalışmalarda kullanulan kuramsal ve yöntemsel yaklaşımlara bağlı olarak bazı çalışmalarda programlarun çok önemli oranda olumlu etki yarattğı tespit edilirken, diğer bazı çalışmalarda programların yeteri kadar etkili olamadığı vurgulanmaktadır. Sosyal bilimsel açıdan bir araştırmada kullanulacak yöntemsel yaklaşım büyük ölçüde analize tabii tutulacak problemin formüle edilmesine ve bu problemin kuramsal çerçeveye oturtulmasına bağhıdır. Bazı araştırmacılar "toplumsal deney" yaklaşımını program etkinliğini tespit etmede kullanulabilecek tek geçerli yöntemsel yaklaşım olarak görürken, diğer bir grup araştırmac toplumsal deney yaklaşımının olumlu yönünü kabul etmekle birlikte çok ciddi sınırlılıklar içerdiğini vurgulamaktadır (HECKMAN/SMITH, 1996). Bu nedenle önerdikleri yaklaşım deneysel olmayan değerlendirme yöntemidir.

Program değerlendirmelerinde bir diğer yaklaşım ise süreç değerlendirmesi diye adlandınlan yaklaşımdır. Süreç değerlendirilmesi bir eğitim programınun oluşturulmasından başlayarak programın yürüttülmesinin çeşitli aşamalarını analizi tabii tutan bir yaklaşımdır (SCHMID, 1996). Sürȩ araştırması yaklaşımına göre, programın yürütülme aşamasındaki farklllıklar, alınan kararlar ve programı yürütme becerisi bir eğitim programının başarısında ya da başarısızlı̆ında önemli göstergeler olarak algılanmaktadır. Hasan (1991) süreç değerlendirmesinin iki önemli ayağının olduğunu vurgulanmaktadır. Bunlardan süreci gözlemleme (monitoring), programın tasarımı ve yürütülmesinin program amacına uygun olup olmadığın belirlerken, süreci kontrol etme, programın yürütülmesinin etkin bir şekilde yürütülüp yürütülmediğini belirleyebilmektedir. Bu çerçevede süreç değerlendirmesi "yukarıdan aşağıya" doğru sürecin nasıl işlediğini tespit etmeyi ve bu süreç içerisinde sorunları belirlemeyi hedeflemektedir. Süreç değerlendirmesi, program etkinliğinin tespit edilmesinde niteliksel verilere (karar metinleri, yönetmelik ve programın uygulanmasında takip edilen kurallar, hukuki belgeler, yönetim mercilerindeki iş bölümü vs.) dayanmakta ve bu veriler temelinde program etkinliği daha çok betimsel olarak sergilenmeye çalışlmaktadır. Programlar birden fazla yerde ve mercide yürütülüyorsa, farklı birimler arasında karşılaşlan farklulıkları tespit etmede ve hangisinin daha etkin olarak yürütüldüğünü belirlemede süreৎ değerlendirmesi önemli bir yaklaşım olarak kabul edilmektedir.

Öte yandan program etkinliğini değerlendirmede kullanulan bir başka ayırım program-merkezli ve hedef-kitle merkezli değerlendirme yöntemidir (WHOLEY/HATRY/NEWCOMER, 1994). Program-merkezli ve hedef-kitle merkezli yaklaşım, araştırma yazınında "etki" araştırması olarak nitelendiril- 
mekte ve etki araşırması daha çok niceliksel verilere dayanmaktadır. Program merkezli değerlendirme yöntemi fayda-maliyet analizi temeline dayandırılmakta ve programın etkisi mali göstergeler temelinde ölçülmektedir (DELANDER/NIKLASSON, 1996). Eğer programın nakit cinsinden faydası maliyeti aşıyorsa, programlar başarılı olarak addedilmekte, program katılımclarının nakit cinsinden ölçülemeyen kazanumları ise analize dahil edilmemektedir. Program merkezli araştırma yaklaşımı programlar arasında geçişi sağlayabilecek önemli ip uçlan sağlayabilmektedir. Buna mukabil, programa katılanlanın gözlemlenebilir özellikleri ve çeşitli kazanımları bu araştırma yaklaşımında pek dikkate alınmamaktadir.

Öte yandan, hedef kitle merkezli program değerlendirmeleri, programlarun etkisini programa katılanların çeşitli kazanumlan temelinde yapmakta ve bu temelde programın etkisini tespit etmeye çalışmaktadır. Hedef-kitle merkezli araştırma yaklaşımı, program merkezli araştırma yaklaşımınun analize dahil ettiği bazı göstergeleri de analize dahil etmektedir. Bu bağlamda programın fiziksel ve mali göstergeleri ve programin uygulama süreci ve performans göstergeleri bu yaklaşımda da büyük önem taşımaktadır.

Bizim bu çalışmada kullandığımız yaklaşıma geçmeden önce bir noktayı vurgulamanun yerinde olduğunu düşünüyoruz. Eğitim programlarının etkinliğini ölçmeye çalışan sosyal bilimcilerin bağlı olduğu disiplin, kullanılan araşturma yaklaşımınun seçiminde büyük önem taşımaktadır. Örneğin, iktisatçlar daha çok program-merkezli araştırma yaklaşımını benimserken ve programların etkinliğini fayda-maliyet temelinde ölçmeye çalı̧ırken, eğitim veya yönetim bilimlerine mensup sosyal bilimciler daha çok süreç araştrrmasına ağırlık vermektedir. Sosyoloji disiplinine mensup sosyal bilimciler ise program etkinliğini ölçmede daha çok programa katılanların sosyal, iktisadi ve psikolojik kazanımlarına ağırlık vermekte ve bu temelde programları değerlendirmektedir.

Biz program etkinliğinin ölçülmesinde kullanılması gereken en etkin yaklaşımın yarı deneysel eşleştirme yaklaşımının olduğuna inanmakla birlikte bu yaklaşım bu araştırmada kullanılamamıştır. Yarı-deneysel eşleştirme yöntemi, programa katılan kitlenin gözlemlenebilir özelliklerine sahip bir kontrol grubunun tespit edilmesini gerektirmektedir. Bu yöntemde, programa katılan kursiyerler (araşturma grubu) ile programa katılmayan ancak programa katılan kursiyerlerin özelliklerine sahip kontrol grubuna, aynu ölçme aracı ya da araçları uygulanarak, iki gruba iliş̧kin sonuçların karşılaştırılması yapılmaktadır (VARÇIN, 1998). Böylece aradaki fark, program etkinliğinin bir göstergesi olarak değerlendirilmektedir. Ancak, bu araşturmada programa katılan kursiyerlerin özelliklerine sahip kontrol grubunu oluşturmak için yeterli sayıda eşleştirilecek bir grubun bulunmaması, bu yöntemin kullanılmasını imkansızlaşturmıştır. Bu araştırmada süreç araştırmasınun ve hedef-kitle merkezli yaklaşımın tüm olası araçları kullanularak program değerlendirilmeye çalışılmıştır. 
Araşturmada süreç araştırmasınun temel öğesi olan kursiyerlerin programa katulmadan önceki durumlan baz alınarak kurs süresince geçirmiş olduklanı evreler, her evredeki kazanımlan, eğitim programunun işleyişi, program sonunda kursiyerlerin kazanumları, eğitim programının etkisi görüşme formu aracalığı ile tespit edilmeye çalışlmıştır. Bütün bu çalışmalar, programun sorunsuz işlediği ve çok iyi yapılandınldığı gibi bir ön kabule dayanmadığı için, programın bütün getirileri ve olası eksiklikleri programa katılan kursiyerlerin görüşleri temel alınarak analize tabii tutulmuştur.

Program değerlendirilmesi dört ana tema üzerine odaklaşmıştır. Bunlardan birincisi, programa katilan kursiyerlerin programa hangi saiklerden hareket ederek katıldıkların, kursiyerlerin eğitim programına katılımlanını olumlu ve olumsuz yönde etkileyecek faktörleri, eğitim programının yürütüldüğü, mekan, araç ve gereçlerin yeterli olup olmadığın, kursiyerlerin konakladığı mekanla ilgili görüşlerini tespit etmeye yöneliktir. Program değerlendirilmesinin ikinci önemli ayağın program içeriğine ilişkin kursiyerlerin kazanımlarının saptanması oluşturmaktadır. Bu amaca yönelik olarak kursiyerin, her derste işlenen temel konular hakkındaki bilgi düzeyi, kurs öncesi ve kurs sonrasında tespit edilmiştir. Bu iki düzey arasındaki farklulık, kursiyerin her derse ilişkin temel konulardaki kazanmlanın göstermektedir. Program değerlendirilmesinin odaklaştığı bir diğer alan ise, eğitim programının program sonrası kursiyerler üzerindeki etkisinden oluşmaktadır. Program değerlendirilmesinin son ayağını, programda ders veren öğretim elamanlan ile programdaki derslerin değerlendirilmesi oluşturmaktadır.

\section{PROGRAM HAKKINDA BILGI VE ARAŞTIRMANIN YŌNTEMI}

Çalışmanun bu bölümünde araşturmaya konu olan eğitim programı hakkunda temel bilgiler verilecektir. Buna ilave olarak araştırmada kullanulan yöntem, örneklemin seçilmesi, verilerin toplanması ve analizine iliş̧in bilgiler yine bu bölümünde sunulacaktur.

\section{Eğitim Programı}

Araştırmaya konu olan eğitim programı Istihdam ve Danışmanlık Hizmetleri (IDH) adı ile anılan ve Ankara Üniversitesi Siyasal Bilgiler Fakültesi tarafından yürütülen sertifika programıdır. Araştırmada bu programın seçilmesinin temel nedeni, programın diğer sertifika programlarından farklı olarak sadece belli bir kurumun personeline yönelik olarak yürütülmesi ve programin iddiasının diğer sertifika programlarına kuyasla çok daha fazla olmasıdır. IDH, SBF ile Türkiye Iş Kurumu (IŞKUR), eski adıyla Iş ve Işçi Bulma Kurumu, arasında imzalanan sözleşme çerçevesinde yürütülmüştür. Sözleşme 
çerçevesinde eğitim programı Ocak 1999'da başlanmış ve 2000 yllınun sonunda tamamlanmıştır. Bu süre içerisinde yaklaşık 300 kişinin sekiz aylık eğitim programindan geçirilmesi planlanmiştır. Sekiz aylık eğitim ikişer aylık dört dönemden oluşmuştur (bkz Çizelge 1: Eğitim Programı Takvimi). Dört dönemin iki dönemi teorik, iki dönemi ise pratik eğitim şeklinde programlanmıştur. Teorik eğitim, istihdam ve danışmanlık hizmetleri ile ilgili çeşitli konuları kapsayan 400 saatlik bir müfredatı içermektedir. 400 saatlik teorik eğitim eşit şekilde; 200 saat olarak iki dönemde verilmiştir (bkz Çizelge 2: Program Müfredatı). Programda yer alan derslerin bazılan tek bir öğretim üyesi tarafından verilirken bazı dersler birden fazla öğretim üyesi tarafından verilmiştir (bkz Çizelge 3: Programda Yer Alan Dersler). Programın müfredatınun temel içerikleri daha önceden hazırlanmış ve SBF'den bu müfredatı uygulaması beklenmiştir. Ancak SBF zaman içerisinde bu müfredatın içeriğinde bazı değişiklikler yapmıştır. Eğitim müfredatı Türkiye Iş Kurumu'nun hizmet alanları üzerinde odaklaşmakla birlikte bazı dersler zemin hazırlamaya yönelik olarak konulmuştur.

Çizelge 1'den anlaşlacağ üzere, 300 kişinin eğitimi 30'ar kişilik 10 grup halinde tasarlanmıştır. Her devrede iki grup eğitime alınmıştır. Dönüşümlü olarak iki grup kursiyer teorik eğitim görürken diğer iki grup kursiyer uygulama eğitiminde bulunmuştur. Eğitim programı SBF bünyesinde kurulan Proje Yürütme Birimi (PYB) tarafından yürütülmüştür. PYB, hem teorik eğitimi hem de uygulama eğitimini koordine görevini üstlenmiştir. Programda ders veren öğretim üyelerinin tamamına yakın Ankara Üniversitesi akademik personelinden oluşmuştur. 
- Ankara Üniversitesi SBF Dergisi • 58-1

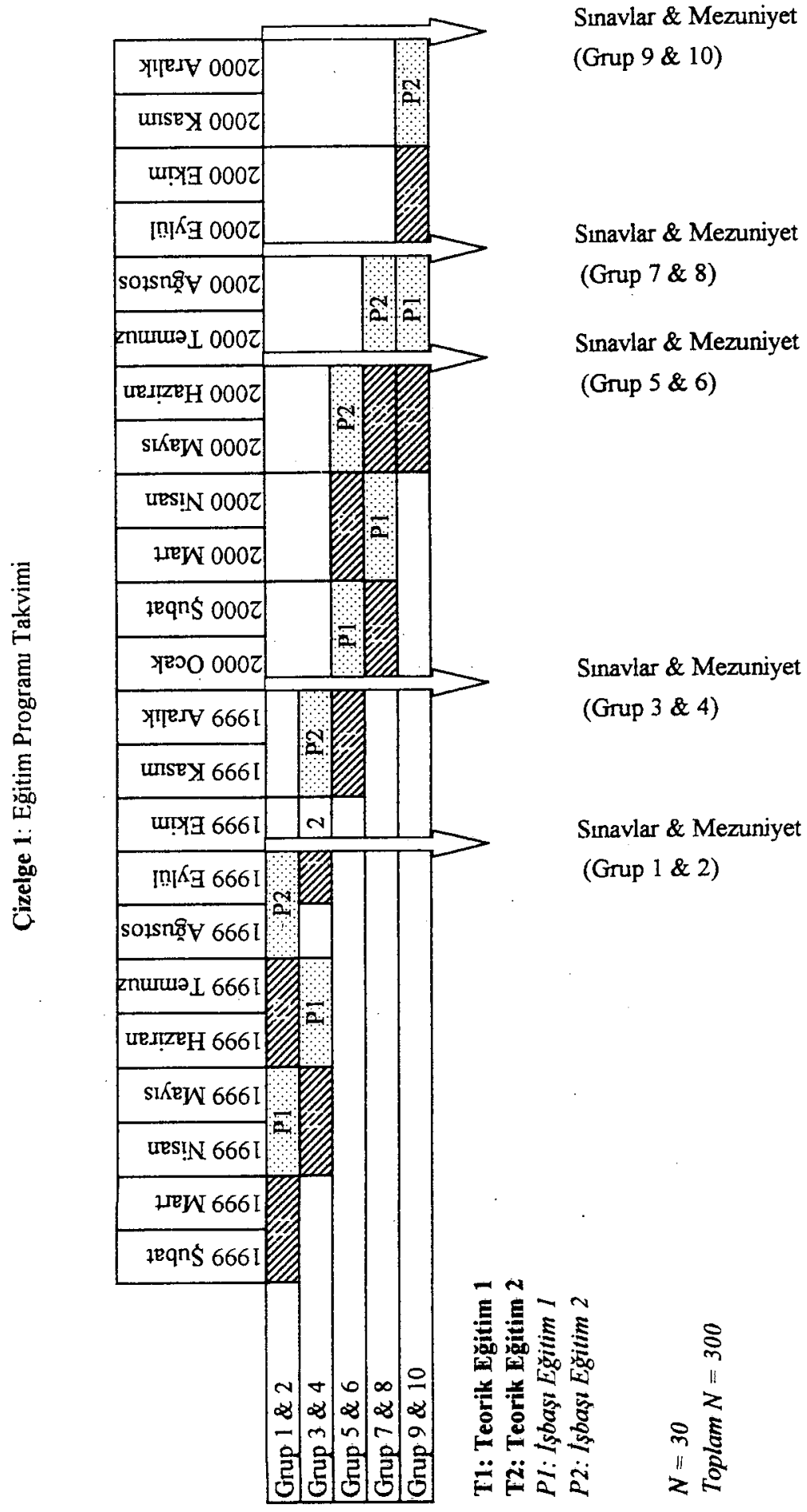


Çizelge 2: Program Müfredatı

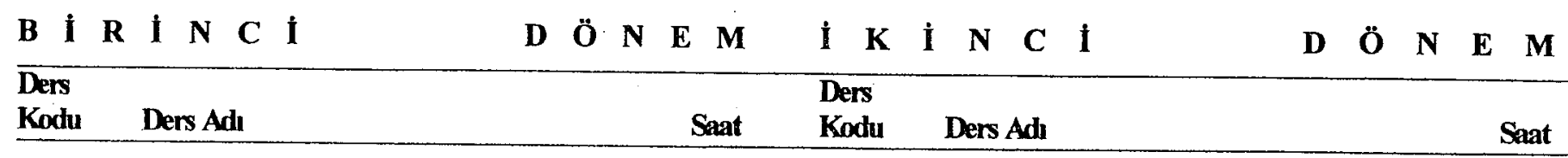

\begin{tabular}{|c|c|c|c|c|c|}
\hline ECS501 & $\begin{array}{l}\text { Işgücu Piyasası ve Istihdam Politikalarının } \\
\text { Temel Prensipleri }\end{array}$ & 40 & ECS503 & İş Organizasyonunun Temel Kavramları & 40 \\
\hline ECS505 & Işglicü Piyasası Bilgileri I & 30 & ECS506 & Işgücü Piyasası Bilgileri II & 30 \\
\hline ECS507 & Bölgesel Işgücu Piyasası tzleme Kaynakları I & 20 & ECS508 & Bölgesel İsgucu Piyasası İzleme Kaynakları II & 20 \\
\hline ECS510 & $\begin{array}{l}\text { Istihdam Hizmetleri için Iş ve Meslek } \\
\text { Bilgileri Yonetimi I }\end{array}$ & 20 & ECS510 & $\begin{array}{l}\text { Istihdam Hizmetleri için Iş ve Meslek Bilgileri } \\
\text { Yönetimi II }\end{array}$ & 20 \\
\hline ECS511 & $\begin{array}{l}\text { Istihdam ve Danışmanlık Hizmetlerinin Hukuks } \\
\text { ve Toplumsal Yönleri I }\end{array}$ & 20 & ECS512 & $\begin{array}{l}\text { Istihdam ve Danışmanlık Hizmetlerinin } \\
\text { Hukuksal ve Toplumsal Yönleri II }\end{array}$ & 20 \\
\hline ECS513 & Görüşme llkeleri ve Teknikleri I & 20 & ECS514 & Görüșme tlkeleri ve Teknikleri II & 20 \\
\hline $\mathrm{ECS} 515$ & Bilgisayar Uygulamaları & 20 & ECS516 & Iş̧e Yerleştirme ve Iș Danışmanlığ II & 30 \\
\hline ECS516 & Ișe Yerleştirme ve Iş Danışmanlı̆ğ I & 30 & ECS518 & Işbirliği ve Yönetim & 20 \\
\hline & Toplam & 200 & & Toplam & 200 \\
\hline
\end{tabular}


Çizelge 3: Programda Yer Alan Dersler

\section{BIIRINCI DŌNEM}

ECS501 Isgücü Piyasası ve Istihdam Politikalarınun Temel Prensipleri

ECS505 Issgücü Piyasası Bilgileri I

ECS507 Bölgesel Isgücü Piyasası tzleme Kaynaklan I ECS510 Istihdam Hizmetleri için Iş ve Meslek Bilgileri Yönetimi

ECS511 Istihdam ve Danışmanluk Hizmetlerinin Hukuksal ve Toplumsal Yönleri I

ECS513 Görüşme Ilkeleri ve Teknikleri I

ECS515 Bilgisayar Uygulamalan

ECS516 Işe Yerleştirme ve Is Danışmanlığı

\section{IKINCI DÖNEM}

ECS 503 Iş organizasyonunun Temel Kavramlan

ECS506 Işgücü Piyasası Bilgileri II

EC5508 Bölgesel İsgücü Piyasası tzleme Kaynakları II

ECS510 Istihdam Hizmetleri için İ̧ ve Meslek Bilgileri Yönetimi II

ECS512 Istihdam ve Danısmanlık Hizmetlerinin Hukuksal ve Toplumsal Yönleri II

ECS514 Görüşme Ilkeleri ve Teknikleri II

ECS516 İşe Yerleştirme ve Iş Danuşmanlığı II

ECS518 Isşbirliği ve Yönetim

Eğitime katılacak kursiyerler IŞKUR tarafından tespit edilmiş olup, bu seçim yapılırken katılımclardan en az iki yıllık yüksek okul mezunu olma şartı aranmıştır. Başlangıçta bu temel ölçütü karşılayan kursiyerler arasından, gönüllü olup olmadığına bakılmaksızın seçim yapıldığı tespit edilmiştir. Kursiyerlerin belirli bir eğitim seviyesine ve çalışma ylına sahip olanlar arasından seçilmesi, verilen eğitimi takip edebilecek yeterlilikte bir grubun oluşmasın sağlamakla birlikte, katılımcıların güdülenmesi açısından temel koşul olan gönüllülük ilkesine dikkat edilmemesinin bazı sorunlara neden olduğu belirlenmiştir.

Programa katılan kursiyerlere kurs süresince "görevli" statüsü verilmiş, kursiyerlerin kursa katılımı ve gereklerini yerine getirmeleri tam-gün iş olarak tanımlanmıştır. Diğer bir ifade ile kursiyerlerden kurs süresince Kurum tarafından herhangi bir görev talep edilmemiştir. Programa Ankara dışından katılan kursiyerlerin barınma ve iaşe bedelleri doğrudan Kurum tarafından karşılanmıştır. Dolayısı ile programa katılım kursiyere ek bir maliyet getirmemiştir. tki haftalık uygulama eğitiminde de kursiyerler, bulundukları şubelerde "geçici görevli" sayılmış ve buralarda da kendilerinden eğitim programı çerçevesinde faaliyette bulunmaları istenmiştir. 
Kursiyerlerin eğitim masraflan ise proje çerçevesinde Siyasal Bilgiler Fakültesi tarafından karşılanmıştır. Kursiyerlere ihtiyaç duyabilecekleri kadar kurtasiye malzemesi (çanta, defter, notluk, kitap, kalem, dosya vs.) verilmiştir. Programla ilgili etkinlik sonuçlan değerlendirilirken, uzun dönem eğitim programuna katılan kursiyerlerin bütün ihtiyaçlarınun Kurum ya da Siyasal Bilgiler Fakültesi tarafından karşılandığını göz önünde bulundurmak gerekir.

\section{Örneklem Çerçevesi ve Verilerin Toplanması}

Istihdam ve Danışmanluk Hizmetleri eğitim programuna IŞKUR Genel Müdürlüğünün çeşitli birimlerinden ve Kurumun taşra teşkilatundan toplam 301 kişi katulmıştır. Bu araştırmanın evrenini 21 Eylül 2000 tarihi itibari ile programdan mezun olan toplam 243 kişi oluşturmaktadır. Araştırmanun yapıldığı dönemde eğitimleri devam eden 9. ve 10. grup kursiyerler bu araşturmada kapsam dışı tutulmuşlardır.

IDH'nin kursiyerler üzerindeki etkisini araştırmayı hedefleyen bu çalışmada, veri toplama yöntemi olarak görüşme formu (anket) kullanılmıştır. Çalışmanun temelini teşkil eden görüşme formunda yer alan sorular ve ifadeler, uzun tartşmalar sonucunda belirlenmiş, görüşme formu ile eğitim programınun kursiyerler üzerindeki etkisi bir çok açıdan değerlendirilmeye çalışılmıştır. Program etkinliğini en iyi şekilde ölçmek amacuyla program etkinliğinin temel alanları tespit edilmiştir. Bu temel alanlar makalenin giriş bölümünde sunulmuştur. Temel alanlarla ilgili etkiyi en iyi şekilde ölçebilmek için çok sayıda soru hazırlanmuştur. Hazırlanan sorular ile taslak bir anket formu elde edilmiş ve bu formun güvenilirliği ve geçerliliği, bir grup kursiyer ile yapılan pilot çalışmada test edilmiştir. Ön çalışmadan elde edilen sonuçlar ışığında rafine bir görüşme formu hazırlanmıştır. Hazırlanan görüşme formu, programa 9. ve 10. grup olarak katilan kursiyerlere programa katıldıkları ilk gün olan 12 Haziran 2000 tarihinde uygulanmuştr. Bu çalışma da geniş anlamda bir pilot çalışma olarak değerlendirilmiştir. Nihai anket formunda 16 'sı açk ve 112 'si kapalı uçlu olmak üzere, toplam 128 soru yer almaktadır. Bu aşamadan sonra üzerinde düşünülmesi gereken konu örneklem çerçevesinin oluşturulması olmuştur. Örneklem çerçevesi, programa katılan kursiyerlerin çalıştıları il, statüleri, programdaki başanlan ve cinsiyet faktörü göz önüne alınarak oluşturulmuştur. Görüşme formunun tamamlanması ve örneklem çerçevesinin oluşturulması ile birlikte verilerin toplanması için bir takvim çkarılmıştur.

Bu aşamada ilk dört grubun (1., 2., 3. ve 4. gruplar) programdan mezun oldukları, ardından gelen dört grubun ise (5., 6., 7.ve 8. gruplar) eğitim programunun farklı aşamalarında bulundukları tespit edilmiştir. Bu nedenle her kursiyer grubuna ulaşmak için farklı bir plan yapılması gerekmiştir. 
IDH'nin etkisinin araştırlması sırasında mümkün olan en yüksek sayıda kursiyere ulaşılması hedeflenmiştir. Diğer bir ifade ile araşturmanun hedef-kitlesi programdan mezun olan tüm kursiyerlerdir. Araşturma kapsamma alınacak kursiyerlerin belirlenmesine ilişkin tasarlanan örnekleme planında, programdan mezun olan kursiyerlerin en az \% 50'sine ulaşma ve eğitimini tamamlamı kursiyerlerin seçiminde zaman ve maliyet kısitlanın göz önüne almak belirleyici faktörler olmuştur.

Örneklemde yer alan kursiyerlerin, kendilerine anket uygulanacağına dair haberlerinin olmaması, bu çalışmanin sonuçlarının güvenilirliği açsından son derece önemli bir nokta olmuştur. Diğer bir ifade ile, programdan mezun olan kursiyerler, görüşmeyi gerçekleştirecek kişi tarafından ziyaret edildiğinde, ziyaretin asıl amaci konusunda son ana kadar bir bilgi edinememişlerdir. Kursiyerin anket formunu ziyaret surasinda kendisinin doldurması da belirtilen nokta açsından önem taşımaktadır. Bu önlemler, kursiyerin hiçbir etki altında kalmaksızın, mümkün olduğunca doğru ve kendisinin olan yantları vermesi amacını taşımaktadır. Görüşme esnasında kursiyerden, görüşme formuna adını soyadını veya kimliğini belirleyecek herhangi bir işaret ya da ibare koymaması istenmiş, bütün bilgilerin bilgisayar ortamında değerlendirileceği belirtilmiş, kişisel bilgilerin hiç kimseye verilmeyeceği vurgulanmış ve böylece daha nesnel verilerin toplanması sağlanmıştr.

IDH'ye katılan kursiyerlerin yaş, eğitim durumu, cinsiyet, çalıştıkları yer ve unvana göre dağılımları ile ömeklemde yer alan kursiyerlerin yaş, eğitim durumu, cinsiyet, çalıştıklan yer ve unvana göre dağllımlan arasındaki benzerlikler seçilen örneklemin temsil gücü açısından önemli bir özelliktir. Çalı̧̧mada öncelikle örneklemin belirtilen değişkenler açsından kitleyi temsil edebilecek nitelikte olup olmadığ incelenmiş ve örneklemin kitleyi temsil edecek nitelikte olduğu görülmüş̧ür. Bu temsiliyet, çalışmanun sonuçlarının güvenilirliği ve sonuçların genel nüfusa genelleştirilebilirliği açısından son derece önemli bir durumdur. Örneklem ile genel nüfusun örtüştüğünü vurgulamak açısından, programdan mezun olan kursiyerler ile ömeklemin genel başarı not ortalamasının birbirine çok yakın olduğunu söyleyebiliriz. Programa katulan kursiyerlerin genel not ortalamas 80.62 iken, örneklem kapsamındaki kursiyerlerin genel başarı ortalaması 80.95 olmuştur.

\section{Kursiyerlerin Sosyo-Demografik özelliklerı}

Eğitim programına IŞKUR'un hem merkez hem de taşra teşkilatlarından katulum olmuştur. Ankara dışından katılan kursiyerlerin oran \%67.1 iken merkez teşkilatından katılan oranı \%32.9'dur. Programa katılan kursiyerlerin ünvanlarında da farklllk göze çarpmaktadır. IDH eğitim programına katılan kursiyerlerin çok büyük bir bölümünü şeflerin (\%42.4) ve memurlann (\%40.3) 
oluşturduğunu görmekteyiz. Eğitim programuna katılan kursiyerlerin \%10.3'ünü de eğitim uzmanı kadrosunda yer alanlar oluşturmaktadır. Diğerlerini de teknisyen ve istatistik uzman kursiyerlerden oluştuğunu görmekteyiz.

Programa katılan kursiyerlerin yaş dağlımı da farklılık arz etmektedir. IDH'ye katılan kursiyerlerin çok büyük bir bölümünün (\%75.3), 31-40 yaş aralığında oldukları dikkat çekmektedir. 25-30 yaş grubunda yer alan kursiyerlerin oranı \%18.1 ve 41-50 yaş grubunda yer alanların oraninun $\% 6.2$ oldukları görülmektedir.

IDH programuna katilan kursiyerlerin \%63.8'ini erkekler, \%36.2 sinin de kadınlardan oluştuğu tespit edilmiştir. Programa katılanların eğitim düzeyleri incelendiğinde, kursiyerlerin \%63.3'ünün Açlk Öğretim Fakültesi (A.Ö.F.), \%36.7'sinin ise üniversitelerin 4 ylllk örgün eğitim bölümlerinden mezun oldukları görülmektedir. A.Ö.F. mezunu kursiyerlerin de yaklaşık üçte ikisi dört yıllık, üçte birinin ise iki yıllık bölüm mezunları oldukları dikkati çekmektedir. Programa katılan dört kursiyerin de yüksek lisans derecesine sahip oldukları tespit edilmiştir.

\section{ARAŞTIRMA BULGULARI}

Giriş kısmunda da belirtildiği üzere, Program değerlendirilmesi dört ana tema üzerine odaklaşmıştır. Bunlar, eğitim programınn yürütüldüğü mekan, araç ve gereçlerin yeterliliğinin incelenmesi, kursiyerlerin eğitim programından kazanımlanının araştırılması, eğitim programının kursiyerler üzerindeki etkisinin ve programda ders veren öğretim üyeleri ile programdaki derslerin değerlendirilmesidir.

\section{Program Hakkında Görüşler ve Performans Değerlendirllmesi}

Bu kesimde IDH'nin uygulandığı yer, süre, araç-gereç, sosyal ve kültürel etkileri özetlenecek ve kursiyerlerin performansları ele alınacaktur. Kursiyerlerin başarı notlanı üzerinde etkili faktörlerin neler oldukları bazı istatistiksel yöntemlerle araşturilacaktur.

Araştırma kapsamına giren kursiyerlerin eğitim süresine ilişkin görüşleri sorulduğunda, sürenin yeterli olduğu ifadesine tamamen katılanların oranı $\% 15.2$, katılanların oran ise \%53.5 olduğu görülmüştür. Bu iki seçenek bir arada ele alındığında, her dört kursiyerden üçünün teorik eğitim süresinin yeterli olduğu düşüncesine katıldığı söylenebilir. Kursiyerlerin \%6.6'sı ise, bu konu hakkında bir fikirlerinin olmadığın belirtmiş; hiç katulmıyorum ve katılmıyorum diyen kursiyerlerin oran da \%24.6 olarak hesaplanmıştr. Bu iki kategoride olan toplam 45 kursiyerin \%72'si Ankara dışından eğitime katulmıştur. 
Örneklem grubunu oluşturan kursiyerlerin büyük bir kısmı (\%94) "Eğitimin Üniversite Ortamında Yapılması Yararlı Olmuştur" düşüncesini dile getirmiştir. Bu konu hakkında bir fikrim yok diyen kursiyerlerin oran $\% 2$ ve bu düşünceye katlmayanların oran ise $\% 4$ 'dür. Bu soruya verilen yanutla kursiyerler, hizmet içi eğitimlerin kurumlarında değil de, bir üniversite ortamında yapılmasının daha yararlı olacağın belirtmişlerdir.

Kursiyerlerin \%28'i "Öğretim Üyeleri Kendi Alanlanında Yetkin Insanlardı" düşüncesine tamamen katılırken, \%49'u katıldıkların ifade etmiştir. Diğer bir ifade ile kursiyerlerin toplam \%79'u öğretim üyelerinin kendi alanlarında yetkin insan olduklarını dile getirmiştir. Burada bu fikre katılmadığın ifade eden 20 kursiyerin eğitim durumlan incelendiğinde 16'sınun 4 yıllık yüksekokul ya da açık öğretim mezunu, 3'ünün iki yıllık yüksekokul ya da açk öğretim mezunu ve $I^{\prime}$ inin de yüksek lisans mezunu olduğu görülmüştür. Kursiyerlerin eğitim düzeyi arttıkça öğretim üyelerinden beklentileri de artmaktadur. Ikinci olarak vurgulanması gereken nokta, programinun kursiyerler üzerindeki etkisinin programı tamamlama sürelerine bağlı olarak değişebileceğidir. Nitekim bu düşünce araştırma sonucunda doğrulanmıştır. Programı çok daha önceden tamamlayan kursiyerler, eğitim programı hakkında çok daha olumlu vurgular yaparken, programa son dönemlerde katılan kursiyerlerde bu olumlu vurgu bu denli gözlenememektedir. Örneğin, programa 1. ve 2. grup olarak katılan kursiyerler öğretim üyeleri ve genel olarak program müfredatının kendilerine kazanımlan konusunda çok daha olumlu düşünürken, programa 7. ve 8. grup olarak katulan kursiyerlerde bu oran düşmektedir. Bu da bize göstermektedir ki, programin etkisi ve kursiyerlerin kazanımları, kursiyerlerin programdan kazanumların yaşamsal pratiğe aktardığı ölçüde kendisini göstermektedir.

Örneklem grubunu oluşturan kursiyerlerin \%56'sı eğitimin verildiği mekanın elverişli olduğunu dile getirmişlerdir. Bu düşünceye katilmayanların oran \%32'dir. Herhangi bir yorum yapmaktan kaçınan kursiyerlerin oran ise $\% 12$ 'dir.

Örneklem grubunu oluşturan kursiyerlerin \%81.2'i ders kitapları, gerekli araç-gereç ve malzemelerin yeterli olduğunu belirtirken; bu düşünceye katulmadığın ifade eden kursiyerlerin oranı \%11.1 ve fikir beyan etmeyenlerin oran da \% 7.7 'dir.

Kursiyerlerin \%26.5’i "Eğitim Süresince Öğretim Elemanlarnyla Olan Sosyal Etkileşim Yararlı Olmuştur" ifadesine tamamen kathlırken, \%55.8'i katıldıklanın belirtmiştir. Buna göre kursiyerlerin büyük bir kısmı (\%82.3) eğitim süresince öğretim elemanlarıyla olan sosyal etkileşimlerin yararlı olduğunu dile getirmişlerdir. Kursiyerlerin $\% 8.8^{\circ} \mathrm{i}$ bu ifadeye katulmadiklarını ifade ederken, \% 8.9'ü ise bir fikrim yok seçeneğini tercih etmiştir. 
Çalışmanun bu bölümünde kursiyerlerin programda gösterdikleri performanslan üzerinde durulacaktur. Burada öncelikle kursiyerlerin başarı not ortalamalarının dağılımı ele alınmıştır. Son olarak, kursiyerlerin başarıları üzerinde açılayıa etkisi olan faktör ve değişkenlerin neler olduğu çoklu doğrusal regresyon modeli ile araşturılmuştur.

Örneklem kapsaminda olan ve başarın notunu beyan eden 178 kursiyere ait mezuniyet not ortalamalarından dördü aykırı değer olduğu için modele dahil edilmemiştir. Kursiyerlere ilişkin not dağllımı Şekil 1'de verilmiştir.

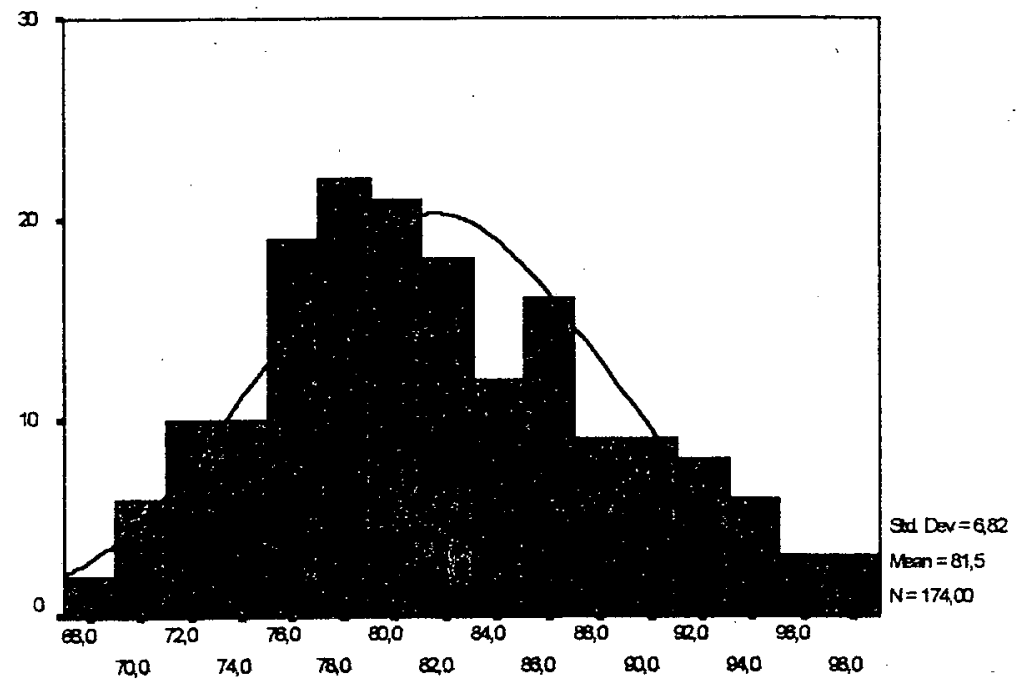

Sekil 1: Not Daguluma

Kursiyerlere ilişkin mezuniyet not ortalamalarınun yaklaşık olarak simetrik bir dağılıma sahip olduğu Şekil 1'de görülmektedir. Incelemeye alınan kursiyerlerin not ortalaması 81.5 ve standart sapması 6.82 olarak hesaplanmıştur. Sapmanun nispeten küçük bir değer çıkması, notların ortalama civarında dağılım gösterdiklerini vurgulamaktadır. Ayrıca, burada görece simetrik bir not dağlımı gözlendiğinden, kursiyerlerin yaklaşık olarak \%68'inin notunun 74.76 ile 88.32 arasında; \%95'inin notunun da 67.86 ile 95.14 değerleri arasında olduğu söylenebilir.

Bu bölümde son olarak, kursiyerlerin başan notlan ile bazı değişkenler arasındaki ilişki ve bağıntlar, çoklu doğrusal regresyon analizi ile araştınımıştır. Başarı üzerinde etkili olabileceği düşünülen potansiyel değişkenler aşağıda verilmiştir.

- Aileden Ayri Olma

- Bilgi ve Beceri Düzeyini Geliştirme Derecesi 
- Bölge (Programa Ankara ve Ankara dışından katılma)

- Cinsiyet

- Eğitim Durumu

- Hizmet Süresi

- Medeni Hal

- Programa Gönüllü Katılma Derecesi

- Sunav Stresi Yaşama

- Teorik Eğitimin Verildiği Fiziki Mekandan Rahatsız Olma

- Yaş (Doğum Tarihi)

- Unvan

Çoklu doğrusal regresyon analizlerinde verileri en iyi tanumlayacak gerekli değişkenlerin modele seçilmesi, modele katkısı önemsiz olan değişkenlerin modelden çkartılması, modelin optimum düzeyde tutulması açsından önem arz etmektedir. Diğer bir ifade ile, başan değişkenini en iyi açıklayacağın düşündüğümüz değiş̧kenler seçilerek nihai modele ulaşılmıştrr. Modelleme çalışmasında en genel modelden başlayarak, aşamalı regresyon analizi ile aşağıdaki nihai model elde edilmiştir. Burada, başarı üzerinde en fazla açılama gücü olan değişkenler, çizelgenin ilk sıralarında yer alan değişkenlerdir. Modele göre yaş, cinsiyet, unvan, sınav stresi yaşama derecesi, programa katıldığı bölge ve bilgi düzeyini artturma güdüsü başan üzerinde istatistiksel olarak anlamlı bulunan değişkenlerdir. Model sonuçları değerlendirilirken göz önünde bulundurulması gereken bir nokta, bölge, unvan, cinsiyet, sınav stresi ve bilgi düzeyini artturma gibi kategorik değişkenlerin kukla değişkenler olarak modele dahil edilmiş olmasıdır. Örneğin unvan¹, "şef", $u_{n v a n^{2}}$ ise "eğitim uzmanı" kadrosunda olan kursiyerlerin diğer unvanlara göre başan üzerindeki etkisini göstermektedir.

\section{Çizelge 4: Model Sonuçları}

$\begin{array}{lllll}\text { Değişkenler } & \text { Katsayı } & \text { S.Hata } & \mathrm{t} \text { Değeri } & \mathrm{p} \text { Değeri } \\ \text { Sabit Terim } & -1184.90 & 201.79 & -5.872 & .000 \\ \text { Doğum Tarihi } & .642 & .103 & 6.264 & .000 \\ \text { Bölge } & 4.428 & .878 & 5.041 & .000 \\ \text { Unvan }^{2} & 6.065 & 1.512 & 4.011 & .000 \\ \text { Cinsiyet } & 3.185 & .926 & 3.440 & .001 \\ \text { Sinav Stresi } & -.930 & .326 & -2.853 & .005 \\ \text { Unvan1 } & 2.908 & .971 & 2.996 & .003 \\ \text { Bilgi Düzeyini Art. Güdüsü } & 2.948 & 1.293 & 2.280 & .024\end{array}$


Modelin belirtme katsayısı 0.62 olarak tahmin edilmiştir. Buna göre, modelde yer alan bu değişkenler kursiyerlerin başarılarındaki değişimlerin \%62'lik bir kısmun açklamaktadır. Burada amaç, incelenen değişkenlerden hangilerinin başarı üzerinde daha çok etkili olduğunu ortaya koyan betimsel bir modelin elde edilmesi olduğundan ve tahmin edilen bu modelin herhangibir kestirim ve öngörü amad gütmemesinden dolayı, belirtme katsayısının nispeten küçük bir değer bir çıkması önemli bir sorun olarak görülmemektedir. Aynca örneklem genişliğinin yeterince büyük olması nedeniyle, kurulan bu model istatistiksel olarak ta oldukça anlamlıdır. Tahmin gücü daha yüksek bir modelin kurulması, modelde yer almayan ancak başan üzerinde önemli olabilecek diğer potansiyel değişkenlerin de modele alınmasıyla mümkün olacaktır.

Ayrıca, araştırma kapsamına giren kursiyerlerin büyük bir kısmı IDH'nin katkısının diğer eğitim programlarına göre çok fazla olduğunu vurgulamışlardır. Programa kathlımda kursiyerleri en fazla güdüleyen faktörlerin bilgi ve beceri düzeyini geliştirme ve yeni bir çevre-yeni arkadaşlar tanma faktörleri olduğu görülmüştür. Performansı olumsuz yönde etkileyen en önemli faktörlerin ise aileden uzakta kalma ve sınav stresi yaşama olduğu belirtilmiştir.

\section{Kursiyerlerin Eğitim Programından Kazanımları}

Bu kesimde program içeriğini oluşturan 21 ana tema konusunda kursiyerlerin kursa katılmadan önceki bilgi düzeyleri ile programi tamamladıktan sonraki bilgi düzeyleri arasındaki farklılıklar incelenmiştir. Kursiyerlerin Program sonrasındaki bilgi düzeylerinde oluşan artışların istatistiksel olarak anlamlı olup olmadığı bağımlı iki grup için t-testi ile araşturlmuştur.

Kursiyerlerin kurs öncesi ve sonrası bilgi düzeylerini temsil etmek üzere likert tipi beşli bir dereceleme ölçeği kullanulmıştır. Düzeylerin değerlendirilmesinde kullanılan ölçek aralıkları aşağıdaki şekilde tanumlanmıştır.

KURS ÖNCESI DÜZEYINIZ

1: Çok yetersiz idi

2: Yetersiz idi

3: Bir fikrim yok

4: Yeterli idi

5: Çok yeterli idi
ŞIMDIKI DÜZEYINIZ

1: Çok yetersiz

2: Yetersiz

3: Bir fikrim yok

4: Yeterli

5: Çok yeterli

Kursiyerlerin kurs öncesi ve sonrası bilgi düzeylerini ölçmek için 21 tema üzerinde hazırlanan sorular aşağıda verilmiştir: 
- Istihdam ve Isssizliği Açklayan Temel Kavramlar Konusundaki Bilgi Düzeyiniz?

- Türkiye'deki Isgücü Piyasasının Tayin Edici Özellikleri Konusundaki Bilgi Düzeyiniz?

- Gelişmiş Ülke Isgücü Piyasaları ile Gelişmekte Olan İsgücü Piyasaları Arasındaki Farklara llişkin Bilgi Düzeyiniz?

- Işgücü Piyasası Verilerinin Toplanması ve Analiziyle ligili Bilgilerinizin Düzeyi?

- Işgücü Piyasası Verilerinin Analizinde ve Değerlendirilmesinde Bilgisayan Kullanma Düzeyiniz?

- Meslek Danışmanlığında Görüşme Sürecine flişkin Pratik Bilgi Düzeyiniz?

- Işinizle Ilgili Olarak Karşılaşth̆ınız (işçi, işsiz, işveren gibi) Kişilere, Işle Ilgili Olarak Ortaya Çıkan Hukuksal Sorunlar Karşısında Ne Derece Yol Gösterici Olduğunuz?

- Istihdam Hizmetlerinin Hukuksal Dayanakları Konusundaki Bilgilerinizin Düzeyi?

- Danışan ile Empatik Bir lletişim Kurma, Onu Olduğu Gibi Kabul Etme, Doğal Davranma, Kendini Somut ffade Etme ve Uygun Soru Sorma Gibi Temel Danı̧̧manlık Becerinizin Düzeyi?

- Iş ve Meslek Danışmanlığı Çalışmalarında Cinsiyet, Özellikle de Kadın Konusundaki Duyarlılık Düzeyiniz?

- Engelli Bireylerle Yapılacak Iş ve Meslek Danışmanlığı Çalışmalarının Hem Ülke Kalkınması Hem de Engelli Bireylerin Kişisel Mutluluğu Açsından Taşıdığı Önem Konusundaki Bilgi ve Tutumunuzun Düzeyi?

- Iş ve Meslek Danışmanliğında Sorunlu Danışanlar Olarak Adlandırılan Grupları Nasıl Tanımlayacağınız ve Onlara Nasıl Yardım Edeceğiniz Konusundaki Bilgi ve Becerilerinizin Düzeyi?

- Bilgisayar Kullanmadaki Beceri Düzeyiniz?

- Sosyal Algı, Nedensel Yaklaşımlar, Tutumlar ve Tutum Değiştirme Konularındaki Bilgi ve Beceri Düzeyiniz?

- Insanların Çalışma Nedenleri, Işlerle Bireyler Arasındaki Uygunluğu Sağlama, Işin Boyutları ve Gerektirdiği Kişisel Özellikler Konusundaki Bilgi Düzeyiniz?

- Temel Yönetim Kavramlar Konusundaki Bilgi Düzeyiniz?

- Devlet Istatistik Enstitüsü' nün Işgücüne tlişkin Istatistiklerinden ve Bunların Içerdiği Bilgilerden Haberli Olma Düzeyiniz?

- Temel Issletmecilik Fonksiyonları ile tlgili Bilgi Düzeyiniz?

- Insan Kaynakları Bölümünün Fonksiyonları ile flgili Bilgi Düzeyiniz?

- Aktif Işgücü Piyasası Programlarınun Çeşitliliği Konusundaki Bilgi Düzeyiniz? 
- Aktif Isgücü Piyasası Programlarınn Etkinliğinin Ölçümünde Kullanulan Yaklaşımlar Konusundaki Bilgi Düzeyiniz?

Yaplan inceleme neticesinde Kursiyerlerin kurs öncesindeki bilgi düzeylerinin genellikle "çok yetersiz idi", "yetersiz idi" ya da "bir fikrim yok" kategorilerinde yoğunlaştı̆ı görülürken; kurs sonrasındaki bilgi düzeylerinin daha çok "yeterli" ya da "çok yeterli" kategorilerinde olduğu görülmüştür. Kursiyerlerin bilgi düzeylerinde gözlenen bu artı̧ın istatistiksel olarak anlamlı olup olmadığı bağımlı iki grup için t-testi uygulanarak araşturlmıştur. Buradaki iddia, kurs sonrasındaki ortalama bilgi düzeyinin kurs öncesindeki düzeye göre artış gösterdiğidir. Test sonuçları Çizelge 5 'te özetlenmiştir. Çizelgeden anlaşlacağı üzere kursiyerler, IDH'yi oluşturan 21 ana tema konusunda önemli kazanımlar elde etmiştir. Kursiyerlerin, başlangı̣ düzeyleri ne olursa olsun, eğitimde verilenlerle her alanda bilgi düzeylerini arttırdıklan tespit edilmiştir. Burada kursiyerlerin kurs öncesi ve sonrası bilgi düzeyleri arasinda istatistiksel olarak önemli farklllkları tespit etmekle birlikte, bu farkhllklarin her alanda aynı olmadığını da görülmektedir. Diğer bir ifade ile bazı derslerde kursiyerlerin kazanımlarının oldukça fazla olduğu, bazı derslerde ise kazanımların bu denli yüksek olmadığı görülmektedir.

Çizelge 5: Kurs Öncesi- Kurs Sonrası Bilgi Düzeyleri

Kurs Sonrasi Kurs Öncesi Ortalama Fark

$\begin{array}{lccccc}\text { TEMA } & \text { Ortalama Düzey } & \text { Ortalama Düzey } & \text { (Sonrasi-Öncesi) } & t & \mathrm{p} \\ 1 & 4.21 & 3.20 & 1.01 & 13.64 & 0.00 \\ 2 & 4.04 & 2.90 & 1.14 & 15.49 & 0.00 \\ 3 & 4.04 & 2.75 & 1.29 & 16.69 & 0.00 \\ 4 & 4.01 & 2.49 & 1.52 & 18.33 & 0.00 \\ 5 & 3.62 & 2.26 & 1.36 & 15.87 & 0.00 \\ 6 & 3.97 & 2.58 & 1.39 & 18.31 & 0.00 \\ 7 & 3.92 & 2.73 & 1.19 & 15.69 & 0.00 \\ 8 & 3.80 & 2.86 & 0.94 & 15.69 & 0.00 \\ 9 & 4.23 & 3.19 & 1.04 & 14.77 & 0.00 \\ 10 & 4.26 & 3.64 & 0.62 & 10.45 & 0.00 \\ 11 & 4.31 & 3.53 & 0.78 & 11.09 & 0.00 \\ 12 & 4.10 & 2.80 & 1.30 & 17.98 & 0.00 \\ 13 & 3.66 & 2.73 & 0.93 & 10.69 & 0.00 \\ 14 & 4.12 & 3.01 & 1.11 & 15.37 & 0.00 \\ 15 & 4.09 & 3.17 & 0.92 & 12.89 & 0.00 \\ 16 & 4.10 & 3.21 & 0.89 & 11.61 & 0.00\end{array}$




$\begin{array}{llllll}17 & 3.85 & 2.61 & 1.24 & 15.97 & 0.00 \\ 18 & 4.03 & 3.16 & 0.87 & 11.61 & 0.00 \\ 19 & 4.15 & 3.11 & 1.04 & 14.83 & 0.00 \\ 20 & 3.88 & 2.78 & 1.10 & 11.59 & 0.00 \\ 21 & 3.71 & 2.55 & 1.16 & 12.64 & 0.00\end{array}$

Farklılı̆ın öğretim üyelerinin performanslarından kaynaklanabileceği iddia edilebilir. Yani bir öğretim üyesi vermiş olduğu dersle ilgili kursiyerleri oldukça donattı̆̆ı, diğer bir öğretim üyesinin ise bu denli başarılı olmadığı iddia edilebilir. Bu iddiayı test edebilmek amacıyla farklı öğretim üyeleri tarafından verilen dersler için daha detaylı analizler yapılmuştır. Programda yer alan ECS501, ECS507-508 ve ECS518 dersleri farklı gruplara farklı öğretim üyeleri tarafından verilmiştir. Bu derslerden sadece birinde (ECS501), kursiyerlerin kazanımlan konusunda bir farklılığın ortaya çktığı, diğer iki derste ise istatistiksel olarak bir farklılığın olmadığı analizler sonucunda ortaya çkmıştır. Burada ders sorumluluları için, kurs öncesi ve sonrasına yönelik özet istatistikler ve ortalama düzeylerdeki artı̧ miktarlan ayrı ayrı elde edilmiştir.

Sonuç olarak, IDH'de yer alan 21 ana tema için kursiyerlerin kazanımları teker teker ele alınmıs ve kursiyerlerin kurs sonrasındaki kazanumlarınun istatistiksel olarak anlamlı olduğu gösterilmiştir. Dersler arasında kazanımlar açısından gözlenen farklılıkların tespit edilmesi amacıyla daha detaylı analizler yapılmıştır. 21 ana tema için kursiyerlerin elde ettikleri kazanumlar topluca Çizelge 6 ' da verilmiştir.

Çizelge 6: Kursiyerlerin Derslere Göre Kazanmlarınun Sıralanması

$\begin{array}{cclccc}\text { SIRA NO } & \text { TEMA } & \text { DERSLER } & \begin{array}{c}\text { KURS ÖNCESI } \\ \text { ORT. DÜZEY }\end{array} & \begin{array}{c}\text { KURS SONRASI } \\ \text { ORT. DÜZEY }\end{array} & \text { FARK } \\ 1 & 4 & \text { ECS505/ECS506 } & 2.49 & 4.01 & 1.52 \\ 2 & 6 & \text { ECS513/ECS514 } & 2.58 & 3.97 & 1.39 \\ 3 & 5 & \text { ECS505/ECS506 } & 2.26 & 3.62 & 1.36 \\ 4 & 12 & \text { ECS505/ECS514 } & 2.80 & 4.10 & 1.30 \\ 5 & 3 & \text { ECS501 } & 2.75 & 4.04 & 1.29 \\ 6 & 17 & \text { ECS507/ECS508 } & 2.61 & 3.85 & 1.24 \\ 7 & 7 & \text { ECS511/ECS512 } & 2.73 & 3.92 & 1.19 \\ 8 & 21 & \text { ECS516 } & 2.55 & 3.71 & 1.16 \\ 9 & 2 & \text { ECS501 } & 2.90 & 4.04 & 1.14 \\ 10 & 14 & \text { ECS516 } & 3.01 & 4.12 & 1.11 \\ 11 & 20 & \text { ECS516 } & 2.78 & 3.88 & 1.10 \\ 12 & 9 & \text { ECS513/ECS514 } & 3.19 & 4.23 & 1.04\end{array}$


Recep Varçın - Gil Ergïn • Bir Oz Denetim Pratigi Olarak Etkinlik Olçamu ve Universiteler • 169

$\begin{array}{lcllll}13 & 19 & \text { ECS503 } & 3.11 & 4.15 & 1.04 \\ 14 & 1 & \text { ECS501 } & 3.20 & 4.21 & 1.01 \\ 15 & 8 & \text { ECS511/ECS512 } & 2.86 & 3.80 & 0.94 \\ 16 & 13 & \text { ECS515 } & 2.73 & 3.66 & 0.93 \\ 17 & 15 & \text { ECS516 } & 3.17 & 4.09 & 0.92 \\ 18 & 16 & \text { ECS518 } & 3.21 & 4.10 & 0.89 \\ 19 & 18 & \text { ECS503 } & 3.16 & 4.03 & 0.87 \\ 20 & 11 & \text { ECS513/ECS514 } & 3.53 & 4.31 & 0.78 \\ 21 & 10 & \text { ECS513/ECS514 } & 3.64 & 4.26 & 0.62\end{array}$

Bu çizelgeden ortalama farklılı̆ıı en fazla ECS505 ve ECS506 tşgücü Piyasası Bilgileri I ve II derslerinde yer alan "işücü piyasası verilerinin toplanması ve analizi" temasında yaratıldığı, en düşük ortalama farkllığın ise ECS514 dersinde işlenen "iş ve meslek danışmanlığı çalışmalarında cinsiyet ve özellikle kadın konusundaki duyarlılık düzeyi" temasında olduğu görülmektedir.

Özetleme vurgulamak gerekirse, kursiyerlerin eğitim programından önemli kazanumlar elde ettikleri söylenebilir. Bu kazanımlar derslerin niteliğine göre farklılık arz etmektedir. Burada ayrıca farklılığı analiz ederken dikkat edilmesi gereken önemli bir nokta, kursiyerlerin kurs öncesi ortalama düzeylerinin ne olduğudur. Örneğin ECS505-ECS506 Işgücü Piyasası Bilgileri I ve II derslerinde kursiyerlerin ortalama düzeyi 2.49 'dan 4.01 'e çıarken, farklılığın düşük olduğu temada bu artş 3.63 'den 4.26 düzeyine gelmiştir. Yani kursiyerler farklılığın nispeten düşük olduğu bu derste kendilerini eğitim programına katılmadan önce de yetkin hissettiklerini ifade etmişlerdir.

\section{Programın Kursiyerlerin Mesleki, Psikolojik ve Sosyal Gelişimlerine Etkisı}

Program etkinliğinin araştırıldığı bu çalışmada, kursiyerlerin programdan edinmiş oldukları bilgi ve becerilerin yararını çalıştıklan kurumda görüp görmedikleri, aldıkları eğitimin onların teorik bilgi ve uygulama deneyimi kazanmalarına, mesleki görev ve sorumluluklarını yerine getirmelerine, yürütmekte olduklarn işlerin önemini kavramalanna ve organizasyon kültürü edinmelerine katkıda bulunup bulunmadığı saptanmaya çalışılmıştır. Ayrıca, programı tamamlamış kursiyerlerin kendilerini geçmişe oranla daha güçlü ve daha gelişmiş bireyler olarak görüp görmedikleri, bakış açlarının ve sorun çözme becerilerinin gelişip gelişmediği araşturilmıştur.

Uygulanan eğitim programının kursiyerlerin işlerini daha çok sevmelerine, daha fazla ilgi duymalanna, çalışma coşkusu ve heyecanı kazanmalanna, iş verimliliklerinin artmasına, iş doyumu ve özsaygı düzeylerinin yükselmesine katkıda bulunup bulunmadığı da incelenmiştir. Bunların yansıra alınan 
eğitimin kursiyerlerin empatik iletişim kurabilme, doğal davranabilme, kendilerini somut ifade edebilme gibi temel iletişim becerileri kazanmalanna etkisinin olup olmadığı sorgulanmıştır.

Bulgular incelendiğinde, araşturma grubunu oluşturan kursiyerlerin \%75'inin IDH süresince kazandıklan bilgi ve becerilerin yararın çalıştılan kurumda gördüklerini, \%67'si mesleki görev ve sorumluluklarını öğrenme ve yerine getirmelerine IDH'nin katkı sağladığını, \%73'ü IDH sonrası organizasyon kültürlerinde bir gelişme gözlediklerini, \%75'i IDH sayesinde kendilerini Kurum içinde yeni görev ve pozisyonlan yüklenebilecek güçte hissettiklerini, \%74'ü ise kendilerini işlerinde daha yetkin ve yeterli hissettiklerini ortaya koymaktadır.

Bu araştırma kursiyerlerin kazanımlarını oldukça geniş bir yelpazede tespit etmeye çalıştı̆ından, bütün sonuçları detaylı olarak burada sergilemek oldukça zordur. Ancak, özetle bazı kazanımları vurgulamak gerekir. Bu bağlamda, kursiyerlerin \%94'ü IDH sonrası teorik bilgi düzeylerinde bir gelişme gözlediklerini, \%84'ü uygulama becerilerinin geliştiğini, \%74'ü edinmiş oldukları bilgi ve becerilerin onları işgücü piyasasında yeni alternatifler aramaya yol açacak biçimde geliştirdiğini, \%66'sı IDH'nin yaptıklan işin önemini kavramalarında etkisinin olduğunu, \%57'si IDH'nin işlerine olan ilgi ve sevgilerini artturdığın, \%78'i IDH sonrası morallerinin yükseldiğini, \%73'ü motivasyon düzeylerinde bir yükselme gözlediklerini, \%78'i rapor yazma becerilerinde bir gelişme gözlediklerini, \%63'ü kendilerini daha değerli hissettiklerini, \%84'ü empatik becerilerinde bir artı̧ gözlediklerini, \%69'u kendilerini daha iyi ifade edip daha doğal davranabildiklerini, \%67'si insanlarla daha kolay iletişim kurabildiklerini, \%61'i IDH sayesinde işleriyle ilgili sorunların üstesinden daha kolay gelebildiklerini, \%69'u Problem çözme becerilerinde bir gelişme gözlediklerini, \%87'si IDH'in bakıs açılarını genişlettiğini, \%54'ü IDH'nin çalışma coşkusu ve heyecanlarını artırdığın, $\% 42$ 'si iş doyumlarında bir artı̧ gözlediklerini, \%64'ü iş verimliliklerinin arttı̆ı̆ı, \%64'ü IDH'nin kurum içi iletişim ve işbirliğini geliştirdiğini, \%63'ü IDH sayesinde çalışmakta olduklan kurumu daha iyi tanıdıkların, $\% 68^{\prime} i$ bu tür eğitim programlarının kurumun imajın olumlu yönde etkilediğini, \%57'si kurum içinde yapılan haksızlıklara karşı çkma konusunda kendilerini daha güçlü hissettiklerini dile getirmektedir.

Ayrıca kursiyerlerin \%26'sı IDH sonrası kendilerini çalıştıkları işyerinde daha huzursuz hissettiklerini, \%34'ü amirleriyle daha fazla çatıştıklarını, \%31'i IDH'ye katılmayan mesai arkadaşlarının kendilerini kıskandıkların dile getirmişlerdir.

Sonuç olarak, kursiyerler eğitim programından mesleki, psikolojik ve sosyal gelişimlerine katkı sağlayabilecek önemli kazanımlar elde etmişlerdir. Ancak bu bulgular, eğitim programının azami katkıyı sağladığını göstermemektedir. Eldeki verilerle böyle bir saptamayı yapabilmek oldukça güçtür. 


\section{Programda Okutulan Derslerin Iıgl, Katkı ve Etkisinin DeğerlendirHmesı}

Burada, Program süresince okutulan toplam 16 dersin, kursiyerlerin çalışthğ işyerlerine olan ilgisi, kursiyerlerin görev ve sorumluluklann yerine getirmelerine olan katkısı ve iş arkadaşları ile olan ilişkilerine etkisi gibi faktörler yönünden değerlendirilmesine ilişkin bulgulara yer verilmiştir.

IDH'nun en temel amaa, çapraz eğitim mantiğı serçevesinde çalıştı̆̆ birim ve uzmanlık alan ne olursa olsun, IşKUR'da çalışan ve IDH'ye katulan her elemanın çok yönlü olarak bilgi ve beceri ile donatılmasıdır. Birinci teorik eğitim döneminde yer alan dersler (bakınız Çizelge 2), daha çok istihdam ve, danışmanllk hizmetlerine temel teşkil edecek konulardan oluşurken, ikinci teorik eğitim döneminde bu derslerin uygulamaya aktarılmasına ilişkin konulara ağırlık verilmiştir. Kursiyerler, almış oldukları dersleri üç farklı boyutta ve likert tipi beşli bir ölçek ile derecelendirmişlerdir. Derslerin değerlendirilmesinde temel teşkil eden boyutlar aşağıda verilmiştir:

A: Her bir dersin kursiyerin çalıştğı işyeri ile olan ilgisi,

B: Her bir dersin kursiyerin görev ve sorumlulukların yerine getirmelerine olan katkist,

C: Her bir dersin kursiyerin çalş̧tı̆ı ortamdaki diğer bireylerle ilişkilerine etkisi.

Derslerin değerlendirilmesinde kullanılan ölçek aralıkları aşağıdaki şekilde tanımlanmıştır.

1: Çok zayif

2: Zayif

3: Orta

4: tyi

5: Çok iyi

Toplam 16 dersin üç ayn boyutta değerlendirildiği bu bölümde, elde edilen bulgular sırayla aşağıdaki başlıklar altında tartışılmıştır.

\section{Derslerin Kursiyerlerin Işyerindeki Çalışmalarıyla İıgisi Açısından Sıralanması}

Çalı̧̧manun bu bölümünde, IDH süresince okutulan toplam 16 dersin kursiyerlerin işyerlerindeki çalışmalanyla ne derece ilgili olduğu değerlendirilmeye çalışılmıştr. Çizelge 7'de ve Şekil 2'de görülebileceği üzere, kursiyerlerin işyerlerindeki çalışmalarla en fazla ilgili olduğuna inandıklan dersler aşağıda verilmiştir:

1) Işe Yerleştirme ve Iş Danışmanlığı I,

2) Işe Yerleştirme ve Iş Danışmanlığı II

3) Görüşme Ilkeleri ve Teknikleri II. 
Çizelge 7 : Derslerin Işyerindeki Çalışmalarla Igisi Açısından Sıralanması

ORT. ÖNEM

PUAN SIRASI

ECS516 Işe Yerleştirme ve Iş Danuşmanlığı II

$4.26 \quad 1$

ECS516 Işe Yerleştirme ve Iş Danışmanlığ I

$4.25 \quad 2$

ECS514 Görüşme llke ve teknikleri II

$4.24 \quad 3$

ECS506 Işgücü Piyasası Bilgileri II

4.114

ECS513 Görüşme Ilkeleri ve Teknikleri I

$4.04 \quad 6$

ECS505 Işgücü Piyasası Bilgileri I

$4.00 \quad 5$

ECS511 Istihdam ve Danışmanlık Hiz. Hukuksal ve Toplumsal Yönleri I $\begin{array}{lll}3.92 & 7\end{array}$

ECS512 Istihdam ve Danışmanlık Hiz. Hukuksal ve Toplumsal Yönleri II $3.90 \quad 8$

ECS515 Bilgisayar Uygulamalan

$3.85 \quad 9$

ECS518 Işbirliği ve Yönetim

$3.84 \quad 10$

ECS510 Istihdam Hizmetleri için Iş ve Meslek Bilgileri Yönetimi II

$3.72 \quad 11$

ECS510 Istihdam Hizmetleri için Iş ve Meslek Bilgileri Yönetimi I

$3.67 \quad 12$

ECS508 Bölgesel İsgücü Piyasası tzleme Kaynaklan II

$3.57 \quad 13$

ECS507 Bölgesel Işgücü Piyasası tzleme Kaynaklan I

$3.53 \quad 14$

ECS503 Iş organizasyonunun Temel Kavramlan

$3.18 \quad 15$

ECS501 Işgücü Piyasası ve Istihdam Politikalanın Temel Prensipleri

$3.10 \quad 16$

Kursiyerler tarafından bu bağlamda en ilgisiz kabul edilen üç dersin ise sırasıyla, Işgücü Piyasası ve Istihdam Politikalarının Temel Prensipleri, Is Organizasyonunun Temel Kavramlan ve Bölgesel Işgücü Piyasası Izleme Kaynakları I adlı dersler olduğu görülmektedir. Kursiyerler tarafından ilgisi en fazla olduğuna inanılan derslerin daha çok uygulamaya dönük dersler oldukları dikkati çekmektedir. Kursiyerler tarafından ilgisi düşük olarak alglanan dersler incelendiğinde, bu derslerin daha çok alt yapı oluşturmaya dönük teorik dersler oldukları görülmektedir. Ancak bu derslerin bile kursiyerlerin işyerlerine olan ilgisi orta düzeyde bulunmuştur.

\section{Derslerin Kurslyerlerin Görev ve Sorumluluklarını Yerine Getirmelerine Katkısı Açısından Siralanması}

Burada, Sertifika Programu süresince okutulan derslerin kursiyerlerin görev ve sorumlulukların yerine getirmelerine ne derece katkıda bulunduğu değerlendirilmeye çalışlmıştr. Çizelge 8 ve Şekil $3^{\prime}$ te görülebileceği üzere, kursiyerler işyerlerindeki görev ve sorumlulukların yerine getirmelerine en fazla katkı sağladığına inandıkları dersleri sırasıyla şöyle sıralamaktadırlar : 
1) Işe Yerleştirme ve Iş Danuşmanlığı I,

2) Işe Yerleştirme ve Iş Danışmanlığı II,

3) Görüşme Ilkeleri ve Teknikleri II.

Çizelge 8: Derslerin Kursiyerlerin Işyerlerindeki Görev ve Sorumlulukların Yerine Getirmelerine Katkssı Açsından Sıralanması

\begin{tabular}{|c|c|c|}
\hline \multirow[b]{2}{*}{ ECS516 Işe Yerleştirme ve Iş Danışmanlığı } & \multicolumn{2}{|c|}{$\begin{array}{l}\text { ORT. ÖNEM } \\
\text { PUAN SIRASI }\end{array}$} \\
\hline & 4.20 & 1 \\
\hline ECS516 Işe Yerleştirme ve Iş Danışmanlığı II & 4.16 & 2 \\
\hline ECS514 Görüşme Ilke ve teknikleri II & 4.04 & 3 \\
\hline ECS506 İşgücü Piyasası Bilgileri II & 4.00 & 4 \\
\hline ECS505 Işgücü Piyasası Bilgileri I & 3.89 & 5 \\
\hline ECS513 Görüşme llkeleri ve Teknikleri I & 3.82 & 6 \\
\hline ECS518 Işbirliği ve Yönetim & 3.75 & 7 \\
\hline ECS512 Istihdam ve Danışmanlık Hiz. Hukuksal ve Toplumsal Yönleri II & 3.73 & 8 \\
\hline ECS511 Istihdam ve Danışmanlık Hiz. Hukuksal ve Toplumsal Yönleri I & 3.73 & 9 \\
\hline ECS515 Bilgisayar Uygulamalan & 3.50 & 10 \\
\hline ECS510 Istihdam Hizmetleri için Iş ve Meslek Bilgileri Yönetimi II & 3.39 & 11 \\
\hline ECS508 Bölgesel Işgücü Piyasası tzleme Kaynakları II & 3.39 & 12 \\
\hline ECS510 Istihdam Hizmetleri için Iş ve Meslek Bilgileri Yönetimi & 3.34 & 13 \\
\hline ECS507 Bölgesel Işücü Piyasası tzleme Kaynaklan I & 3.29 & 14 \\
\hline ECS501 İsgücü Piyasası ve Istihdam Politikalannn Temel Prensipleri & 3.10 & 15 \\
\hline ECS503 Iş organizasyonunun Temel Kavramları & 3.09 & 16 \\
\hline
\end{tabular}

Bir önceki konuda olduğu gibi bu konuda da katkısı en az kabul edilen üç dersin surasıyla, Iş Organizasyonunun Temel Kavramları, Işgücü Piyasası ve Istihdam Politikalarının Temel Prensipleri ve Bölgesel Işgücü Piyasası Izleme Kaynakları I adlı dersler oldukları görülmektedir. Kursiyerler tarafından kendilerine en fazla katkı sağladığına inanulan derslerin daha çok uygulamaya dönük dersler olduklan dikkati çekmektedir. Kursiyerler tarafından katkı düzeyi düşük olarak alglanan derslerin ise daha çok alt yapı oluşturmaya dönük teorik dersler olduklan görülmektedir. 
Derslerin Kursiyerlerin Çalışma Arkadaşları, Amir ve Astlarıyla liş̧kilerine Etkisi Ag̨ısından Siralanması

Bu kesimde, IDH süresince okutulan derslerin kursiyerlerin çalıştıkları kurumdaki diğer personelle olan ilişkilerini etkisi saptanmaya çalıșılmıştur. Çizelge 9 ve Şekil 4'te görülebileceği üzere, kursiyerler, işyerlerindeki diğer kişilerle olan ilişkilerini en çok etkilediğine inandıklan dersleri sırasıyla şöyle suralamaktadırlar :

1) ECS516 Işe Yerleştirme ve Iş Danuşmanuğı II,

2) ECS516 Işe Yerleştirme ve Iş Danuşmanlığ I,

3) ECS514 Görüşme tlkeleri ve Teknikleri II.

Kursiyerler tarafından bu bağlamda etkisi en az kabul edilen üç dersin ise sırasıyla, ECS501 Işgücü Piyasası ve Istihdam Politikalarının Temel Prensipleri, ECS503 Is Organizasyonunun Temel Kavramları, ve ECS510 Istihdam Hizmetleri için Iş ve Meslek Bilgileri Yönetimi adlı dersler olduklan gözlenmektedir.

Bu bulgular da Çizelge 7 ve Çizelge 8 'deki bulgularla tutarlllık göstermektedir. Kursiyerler tarafından kendilerine en fazla etkide bulunduğuna inanulan derslerin daha çok uygulamaya dönük dersler oldukları dikkati çekmektedir. Burada yine Kursiyerler tarafından etki düzeyi düşük olarak algılanan derslerin ise daha çok alt yapı oluşturmaya dönük teorik dersler oldukları görülmektedir. Ancak bu derslerin bile kursiyerlerin gelişimine orta düzeyde etkide bulunduklan gözlenmektedir.

Çizelge 9 : Derslerin Kursiyerlerin Çalışma Arkadaşları, Amir ve Astlarıyla tlişkilerine Etkisi

ORT. ÖNEM

PUAN SIRASI

ECS516 Işe Yerleştirme ve Iş Danışmanlığı II

$4.07 \quad 1$

ECS516 Işe Yerleştirme ve Iş Danuşmanlığ I

$4.06 \quad 2$

ECS514 Görüşme tlke ve teknikleri II

$4.00 \quad 3$

ECS506 Işgücü Piyasası Bilgileri II

$3.87 \quad 4$

ECS505 Işgücü Piyasası Bilgileri I

$3.85 \quad 5$

ECS513 Görüşme Ilkeleri ve Teknikleri I

3.756

ECS518 Işbirliği ve Yönetim

$3.68 \quad 7$

ECS512 Istihdam ve Danışmanlık Hiz. Hukuksal ve Toplumsal Yönleri II

$3.54 \quad 8$

ECS511 Istihdam ve Danışmanlık Hiz. Hukuksal ve Toplumsal Yönleri I $3.53 \quad 9$

ECS515 Bilgisayar Uygulamalan 
ECS510 Istihdam Hizmetleri için Iş ve Meslek Bilgileri Yönetimi II $3.19 \quad 11$

ECS508 Bölgesel Issgücü Piyasası tzleme Kaynaklan II

3.1812

ECS507 Bölgesel Işgücü Piyasası Izleme Kaynaklan I

$3.14 \quad 13$

ECS510 Istihdam Hizmetleri için Iş ve Meslek Bilgileri Yönetimi I

$3.08 \quad 14$

ECS503 Iş organizasyonunun Temel Kavramlan

$3.01 \quad 15$

ECS501 Işgücü Piyasası ve Istihdam Politikalarınun Temel Prensipleri

$2.85 \quad 16$

Bu bölümde, IDH süresince okutulan toplami 16 dersin, kursiyerlerin çalıştğı işyerlerine olan ilgisi, kursiyerlerin görev ve sorumluluklann yerine getirmelerine olan katkısı ve iş arkadaşlan ile olan ilişkilerine etkisi gibi faktörler yönünden değerlendirilmesine ilişkin bulgulara yer verilmiştir. Sonuç olarak, Birinci Teorik Eğitim Döneminde okutulan dersler arasında bir sıralama yapıldığında, ilgisi, katkısı ve etkisi en yüksek bulunan derslerin, sirasıyla ECS516 Işe Yerleştirme ve Iş Danışmanlığı I, ECS505 Işgücü Piyasası Bilgileri I ve ECS513 Görüşme tlkeleri ve Teknikleri I dersleri olduğu görülmektedir. Ikinci Dönemde okutulan dersler incelendiğinde de yine benzer bir tablo ile karşılaşılmıştır. Bu dönemde okutulan dersler arasında ilgisi, katkısı ve etkisi en fazla olduğuna inanulan derslerin surasıyla ECS516 Işe Yerleştirme ve Iş Danışmanlığı II, ECS514 Görüşme llkeleri ve Teknikleri II ve ECS506 Işgücü Piyasası Bilgileri II adlı dersler olduğu görülmektedir.

\section{SONUÇ}

Üniversiteler gittikçe artan oranda ve birbirleri ile rekabet edercesine geleneksel lisans ve lisansüstü programlarına ilave olarak çok çeşitli eğitim faaliyetleri içerisinde bulunmaktadırlar. Bu faaliyetler arasında "danı̧̧manlık" hizmetleri olarak adlandırılan faaliyetler de yer almaktadır. Öyle gözüküyor ki, bu tür faaliyetler üniversitelerin ve dolayısı ile öğretim elamanlarının gittikçe artan oranda gündemini isgal edecektir. Son olarak Ankara Üniversitesi'nin Sürekli Eğitim Merkezi'ni (ANKÜSEM) kurması bu konudaki faaliyetlerin gittikçe artacağın göstermektedir. Ankara Üniversitesi rektörü, üniversitelerin bu yeni işlevini öz bir ifade ile dile getirmektedir: "Günümüzde üniversiteler, araşturma ve öğretim işlevlerine ek olarak üçüncü bir işlevi üstlenme gereği duymaktadırlar. Bu işlev, bilgiye ihtiyaç duyulan toplumsal sorunların çözümünde danışmanlık yapma ve yaşamboyu eğitim hizmeti sunmaktur." (ARAS, 2002). Aras'in bu ifadesi, bu konudaki gözlemimizi ve öngörümüzü doğrular niteliktedir.

Lisans ve lisansüstü eğitime ilave olarak adına yaşamboyu eğitim denilen eğitim programlarının etkisine ilişkin bir çalışmanın olmayışı Alman menşeili eğitim anlayışı ile Anglo-sakson eğitim anlayışı arasındaki farkla açklanabilir. 
Birincisinde, ki bu Türkiye'de de hakim olan anlayıştr, bir eğitim programı yürütülüyorsa ve bu konuda talep de varsa, mutlaka işe yarıyordur düşüncesi hakimdir. Böyle bir faaliyetin etkisine ilişkin bir çalışmaya da o kadar gerek yoktur. Bu anlayışa göre bir öğretim üyesinin vermiş olduğu dersin öğrenci tarafından değerlendirmeye tabii tutulması bile pek aşina olunan bir durum değildir. Ikincisinde, yürütülen eğitim faaliyetleri kadar o eğitim faaliyetinin ortaya çıardığı etki (impact) de önemlidir. Bu etkinin ortaya çkarılması hem o programın değerlendirilmesi, dolayısı ile olumlu ve olumsuz sonuçlarının belirlenmesi hem de eğitim programlarınun pazarlanması ve talep yaratilması, dolayısı ile rekabetçi konumunu ilerilere taşımak, açısından önem arz etmektedir. Üniversiteler, rekabete dayall bir ortamda sürekli eğitim programları ile piyasa aktörü olmaya hazırlanıyorlarsa, bu faktörü gözden rak tutmamaları gerekir.

Biz bu çalışmada, Ankara Üniversitesi Siyasal Bilgiler Fakültesi tarafından yürütülmüş bulunan bir eğitim programının etkisinin kısmi sonuçların sunmaya çalıştk. Bu sonuçlar kursiyerlerin eğitim programından önemli kazanımlar elde ettiklerini göstermektedir. Eğitim gibi etkisi uzun döneme yayılabilecek ve kendisini hayatun farklı noktalarında gösterebilecek bir yaturımın etkisinin uzun dönemde neler olabileceği ancak meşakkatli bir çalışmanın sonucunda ortaya çıkarılabilir. Bu kapıyı ilerdeki araştırmacılar için açık birakıyoruz.

Yürütülen programın eksiklikleri ve karşılaşılan sorunlarn tespit etmiş olmakla birlikte bu sonuçları da yukarıdaki satırlarda ve kısmen satır aralarında vermeye çalıştık. Çalışmamızın başlığında "öz denetim pratiği ..." ibaresinin yer alması kendimizin de üniversitede istihdam ediliyor oluşumuzdur. Bu çalışma idari bir görevlendirme sonucunda değil, akademik bir kaygı sonucunda gerçekleştirilmiştir. Eksiklikleri ile birlikte bu çalışmanun konu hakkındaki sosyal bilim yazınına bir katkı sağladığı inanandayız.

\section{Kaynakça}

ARAS, Nusret (2002), Ankara Onjversites! Rektörũ olarak ANKUSEM'In kuruluşuna iliș̣kin üniversite ögretim uyelerine gönderdiğı mektup, Mayis 2002.

DELANDER, Lennart / NIKLASSON, Harald (1996), "Cost-Benefit Analysis," SCHMID, G. / O'REIUY, J. / SCHÖMANN. K. Brookfield (eds.), International Handbook of Labor Market Policy and Evaluation (Vermont: Edward Elgar Publishing Company).

Gübenkian Komisyonu (1996), Sosyal Bilimleri Açın (Istanbul: Metjs Yayınları).

HASAN, A. (1991), "Evaluation of Employment, Training and Social Programmes: An Overvlew of Issues," The State of Complex Art (Paris: OECD).

HECKMAN, Smith (1996), "Experimental and Nonexperimental Evaluation," SCHMD, G. / O'REILY, J. / SCHÖMANN, K. Brookfield (eds.), International Handbook of Labor Market Policy and Eualuation (Vermont: Edward Elgar Publishing Company). 


\section{Recep Varçın - Gül Ergün • Bir Oz Denetim Pratiģi Olarak Etkin lik Olçımu ve Universiteler • 177}

SCHMID, G. (1996), "Process Evaluation: Policy Formation and Implementation," SCHMID, G. / O'RELUY, J. / SCHÖMANN. K. Brookfield (eds.), Intemational Handbook of Labor Market Policy and Eualuation (Vermont: Edward Elgar Publishing Company).

SCHMID, G./ O'RELLY, J./ SCHÓMANN. K.. (1996). "Theory and Methodology of Labour Market Policy and Evaluation: An Introduction," SCHMD, G. / O'REILLY, J. / SCHŐMANN, K. Brookfleld (eds.), Intemational Handbook of Labor Market Policy and Evaluation (Vermont: Edward Elgar Publishing Company).

ÖZLEM, Doğan (1998), "Doğa Bilimleri Sosyal Bilimler Aynmı Olstüne," Toplum ve Bilim. No.76.

OZUJđ̆URLU, Metin (1998) "Haleden Altun Biteziğe Bilim ve Oniversite Sanayl Işbirliglı," Ankara Oniversitesi, Siyasal Bilgiler Fakültesi, Tartusma Metinieni, No: 9.

VARÇIN, Recep, (1998), 'QuasI-Experimental Design Methodology on the Effectiveness of Active Labor Programs: Study Design for Turkey," Human Deuelopment Confenence, Washington D.C., 4-6 March, 1998.

WHOLEY, J./ HATRY, P./ NEWCOMER, F. (1994), Handbook of Practical Program Evaluation (San Francisco: Jossey-Bass Publishers). 
Ek Şekil-2. Derslerin İlgisi

圆 Çok Zayıf 图Zayıf 圆 Orta 圈 lyi $\square$ Çok iyi

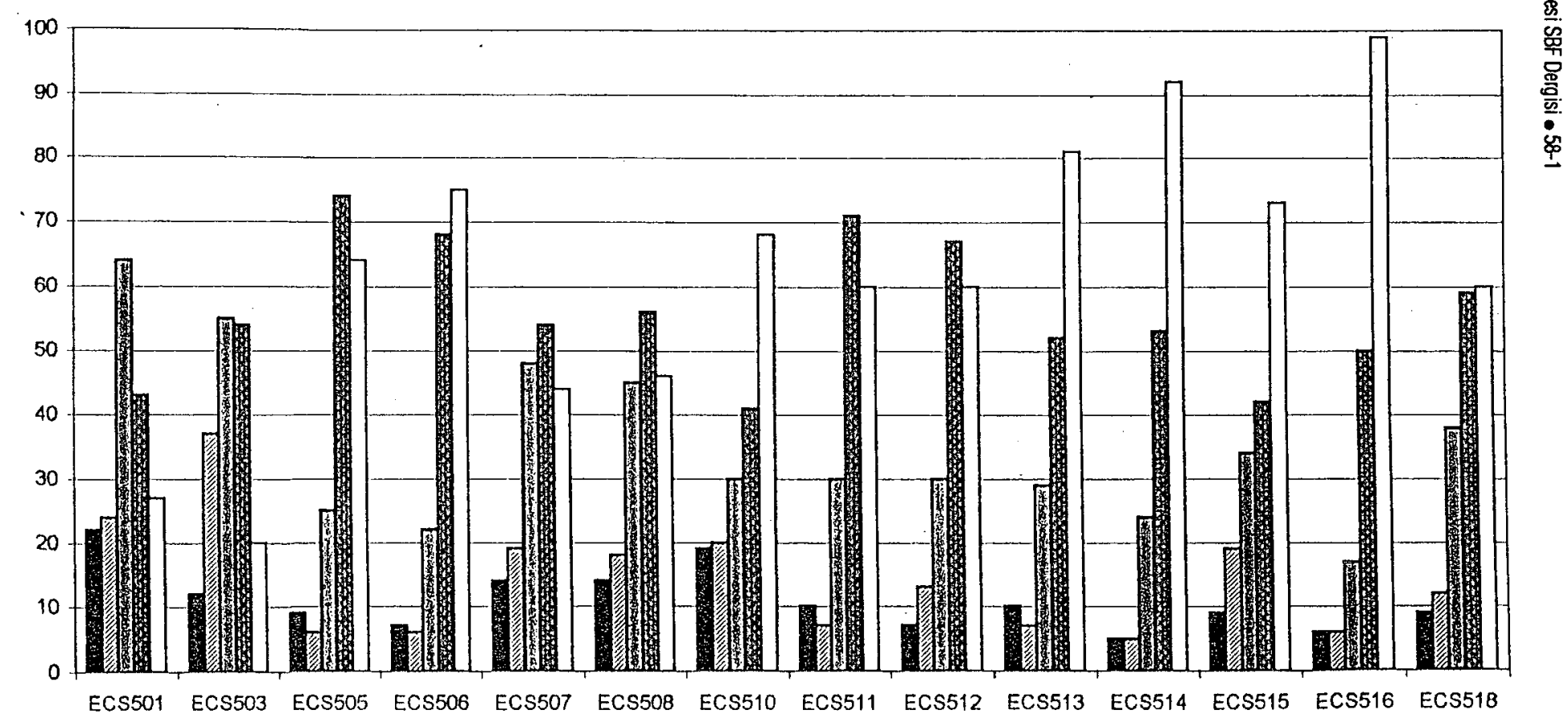


Ek Şekil-3. Derslerin Katkısı

Çok Zayı Zayıf w Orta \$ lyi O Çok iyi

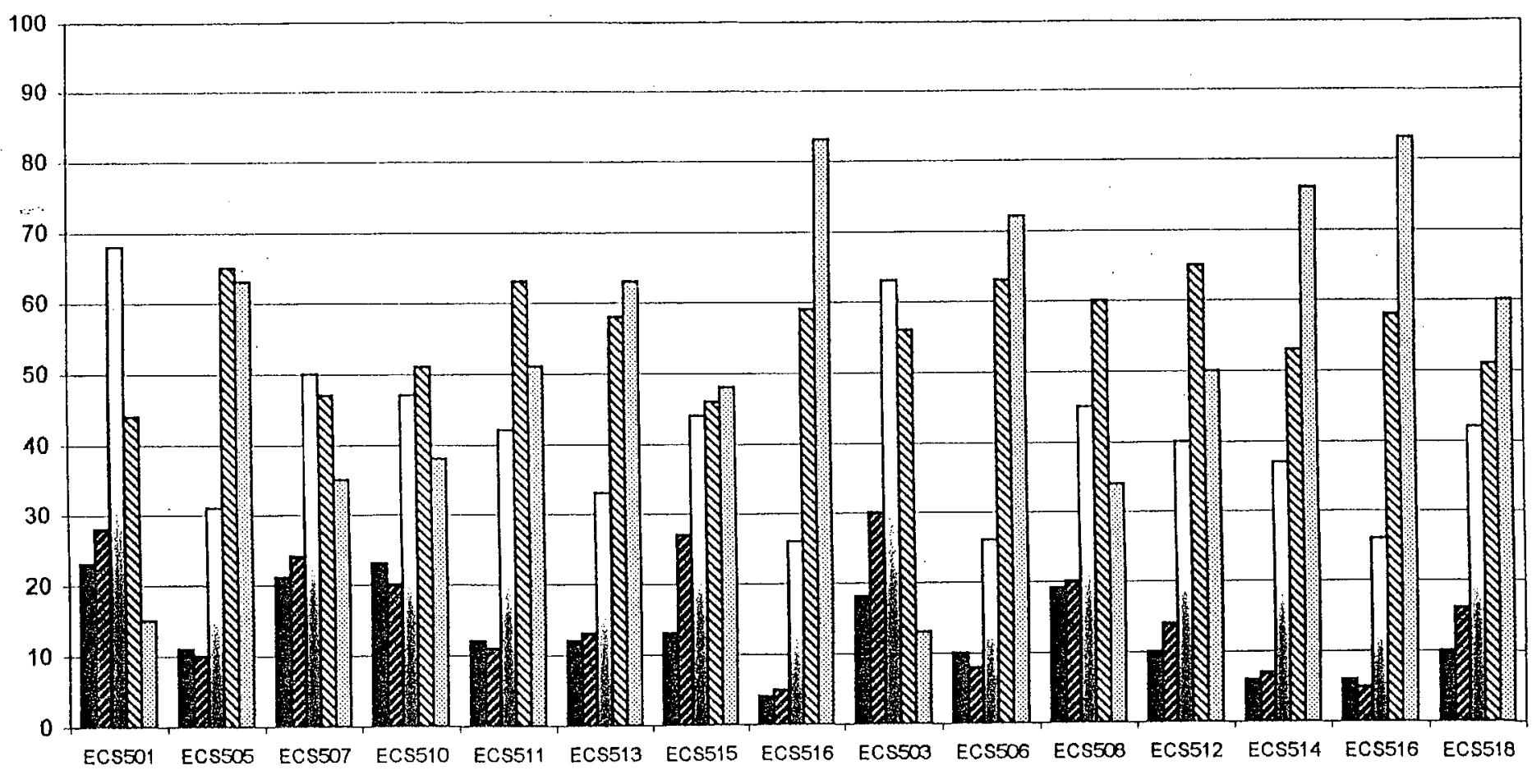


Ek Şekil-4. Derslerin Etkisi

종 Çok Zayıf 图 Zayıf Orta $\square$ lyi $\square$ Çok iyi

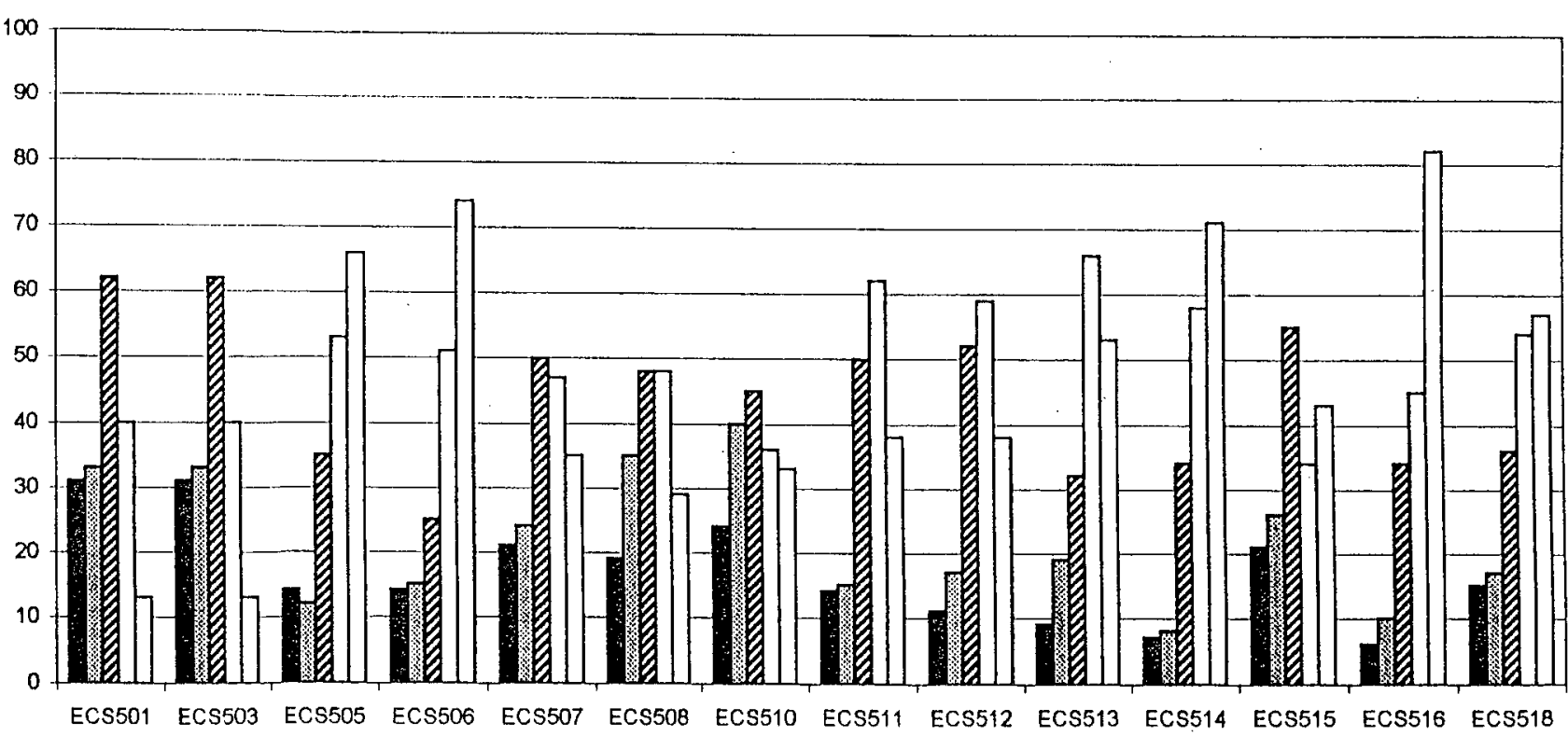

